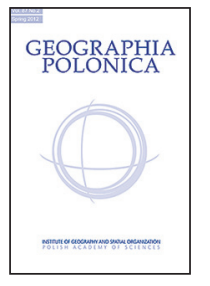

\title{
LANDSCAPE TEXTURE IN ANTHROPOGENICALLY TRANSFORMED REGIONS: THE EXAMPLE OF UPPER SILESIA AND THE DACBROWA COAL BASIN (SOUTHERN POLAND)
}

\section{Katarzyna Pukowiec-Kurda}

Faculty of Earth Sciences

University of Silesia

Będzińska 60, 41-200 Sosnowiec: Poland

e-mail: katarzyna.pukowiec@us.edu.pl

\begin{abstract}
In recent years, we see growing importance of research on landscape texture, which enables scientists to assess landscape as to its esthetic (visual), planning, as well as ecological aspects. Analyses of landscape texture result in identification of landscape zones, classified according to their habitability, recreational potential and suitability for industry, which plays a crucial role for work on planning and strategic documents. The study area covers 12 selected municipalities of Upper Silesia and the Dąrowa Coal Basin, which are highly industrialized regions. Combining an analysis of the degree of landscape enclosure/openness with an analysis of morphological diversity in the study area, the author identifies landscape texture units in accordance with the new, more detailed typology. This results in the emergence of 36 landscape texture types that take into account the land relief forms in the study area. For the needs of further analyses, these types are classified into three groups: open, mosaic and enclosed landscapes.
\end{abstract}

\section{Key words}

landscape texture - landscape openness indicator $\bullet$ open landscape $\cdot$ mosaic landscape $\bullet$ enclosed landscape

\section{Introduction}

Research on landscape physiognomy is among topics that enjoy little popularity among geographers, however, it plays a crucial role for landscape architecture and the so-called geoecology. Although landscape physiognomy had been studied already at the turn of the 20th century, it was the development of IT that provided tools suitable for mul- ti-aspect physiognomic analyses (e.g. De Veer \& Burrough 1978; Brossard \& Joly 1996; Miller \& Law 1997). Also in Poland, research analyzing spatial diversity of landscapes from the point of view of their physiognomy has been carried out, for instance by Richling (1992), Bogdanowski (1999), Śleszyński (2007) and Chmielewski et al. (2018). Within this research field, studies on landscape texture based on analyses of land cover and 
morphology have been rising in prominence recently (Plotnick et al. 1993; Fischer et al. 2008; Chmielewski et al. 2014). Such studies enable scholars to assess landscape as to its esthetic aspects (e.g. by means of landscape panorama analysis) and identify its sanitary value. The latter aspect is related to the connections between landscapes and their inhabitants' standard of living and health (Ulrich 1979) and is particularly important in the context of current anthropogenic changes (Ward Thompson 2011).

Landscape texture describes the internal structure of a landscape, reflected in landscape physiognomy and considered on the basis of the local morphological conditions and the degree of landscape enclosure/ openness. It is defined depending on the degree to which a landscape unit is filled with surface, linear and spot elements. Landscape texture analyses provide information about the vertical layout of landscapes but also about the patterns of spatial distribution of land cover elements (Bell 2004) and landscape granularity (Chmielewski T.J. \& Chmielewski Sz. 2015). Landscape texture allows us to assess the landscape openness indicator (Weitkamp 2010), i.e. the feature resulting from a landscape being composed of low elements, enabling an observer to see the whole horizon or a part thereof (Plit \& Myga-Piątek 2014). Usually, this is a positive feature, as open landscapes (e.g. not covered by buildings or forests) are believed to possess higher ecological and sanitary value.

Many foreign authors have carried out landscape texture analyses, identifying the degree of landscape openness. A study on landscape perception by Kaplan et al. (1989) shows that landscape openness is one of the main features that determine the visual and esthetic assessment of a landscape. Likewise, in a study on perception of countryside landscapes carried out by Rogge et al. (2007), landscape openness was among the most important features respondents focused on. As regards the agricultural landscape in the north of the Netherlands, openness is perceived as an asset, because it gives an observer the possibility to see the horizon (Coeterier 1996). Weitkamp et al. (2011) assess the degree of landscape openness by means of GIS tools.

Also Polish scholars have examined landscape texture, determining landscape openness. Plit \& Myga-Piątek $(2014,2016)$ report on their research on the degree of landscape openness/enclosure and its esthetic assessment in the context of landscape evolution. They treat the degree of landscape enclosure as an indicator of gradual evolutional changes that relate both to physical geography and to culture. Szulczewska and Kaliszuk (2005) analyze the concept of urban ecosystems, and they point out that open areas constitute a crucial part of such ecosystems, playing an important role in their smooth functioning. An original method of landscape texture analysis has been proposed by Chmielewski et al. (2014), focusing on the Roztocze Range. The method involves delineation of landscape texture units on the basis of an analysis of the background and the elements located against this background. They classify the delineated units into 5 landscape texture types: open landscapes, inlaid (incrusted) landscapes, dissected landscapes, labyrinth and mosaic landscapes, and covered landscapes. Chmielewski et al. (2018) examine the physiognomic structure of the Polesie National Park and propose a more detailed version of their previous typology (Chmielewski et al. 2014), including 6 landscape types.

Considering the present need for research on landscape quality in Poland, in areas where natural as well as anthropogenic backgrounds dominate, this paper endevours to analyze landscape texture in areas changed by human impact. An attempt to apply the original typology of landscape texture units (Chmielewski et al. 2014, developed in. Chmielewski et al. 2018) to anthropogenically transformed areas (Katowice, Sosnowiec) has revealed the need to modify it. Consequently, this typology has been developed to include more details, increasing the number of identifiable units from 5 to 9 . The main aim of this paper is to verify the 
new landscape texture typology and to test its applicability to anthropogenically transformed areas.

\section{Materials, Method and Study Area}

\section{Materials}

Landscape texture units are delineated on the basis of morphological units analyzed according to the degree of landscape enclosure/ openness. Morphological units are identified on the basis of a Digital Terrain Model (DTM with counter interval of $10 \mathrm{~m}$ ), a contour map of the area and a map showing slope angles. The degree of landscape enclosure/openness is assessed on the basis of a 1:50,000 topographic map of the area, supplemented with an up-to-date orthophotomap.

\section{Identification of landscape texture units}

Morphological units serve as the data enabling us to identify landscape texture units. Four types of morphological units were identified:

1. Valleys - oblong areas with flat bottoms, stretching for a few up to a few dozen kilometres, hypsometrically clearly lower than the neighbouring areas.

2. Gentle slopes - areas located between valleys and plateaus, with a maximum gradient below $2 \%$.

3. Steep slopes - areas located between valleys and plateaus, with a minimum gradient of $2 \%$.

4. Plateaus - top parts of hillocks and hills, flat areas surrounding those top parts.

Research on landscape texture is based on analyses of morphological diversity and the degree of land cover, without making a distinction between natural and anthropogenic forms. A landscape texture unit emerges from a combination of a specific land relief form with the degree of openness/enclosure. The latter is assessed on the basis of a 9-point scale, in which a homogeneous landscape background (open or enclosed landscape) may be inlaid with linear or insular elements (or both). Moreover, mosaic landscapes constitute an intermediate stage between open and enclosed landscapes, as it is not possible to unequivocally determine whether their background is open or enclosed. Landscape background is understood in accordance with the definition proposed for the needs of landscape audits (Solon et al. 2015: 31). The degree of landscape enclosure/openness is illustrated in Figure 1.

The detailed typology of landscape texture types includes 9 possible degrees of landscape enclosure/openness:

A - open - large, physiognomically homogenous forms with a clearly visible horizon, e.g. large agricultural areas, water bodies, steppes, deserts, etc.;

B - open with inlaid linear elements large, physiognomically homogenous forms constitute the background, with visible lower or higher winding, continuous linear elements, e.g. gorge cuttings, overgrown accumulation valleys, balks and strips of bushes, winding field paths, often bordered by trees, including fruit trees, etc.;

C - open with inlaid insular elements large, physiognomically homogenous forms constitute the background, with visible higher islands of different land cover, e.g. small groves, clumps of trees, ponds, etc.;

$B C$ - open with inlaid linear and insular elements - large, physiognomically homogenous forms constitute the background, with visible higher linear and insular forms (patches) with different, heterogeneous land cover, e.g. a system of agricultural fields with balks bordered by trees and scattered buildings;

D - mosaic - physiognomically diverse, heterogeneous and without uniformity, often having a chaotic, haphazard structure, with diverse land cover forms without a clearly dominant one, may be cut with linear elements, e.g. a village with single-family housing, gardens and neighbouring fields, shops and other facilities;

EF - enclosed with inlaid insular and linear elements - large, physiognomically homogenous forms constitute the background, with 


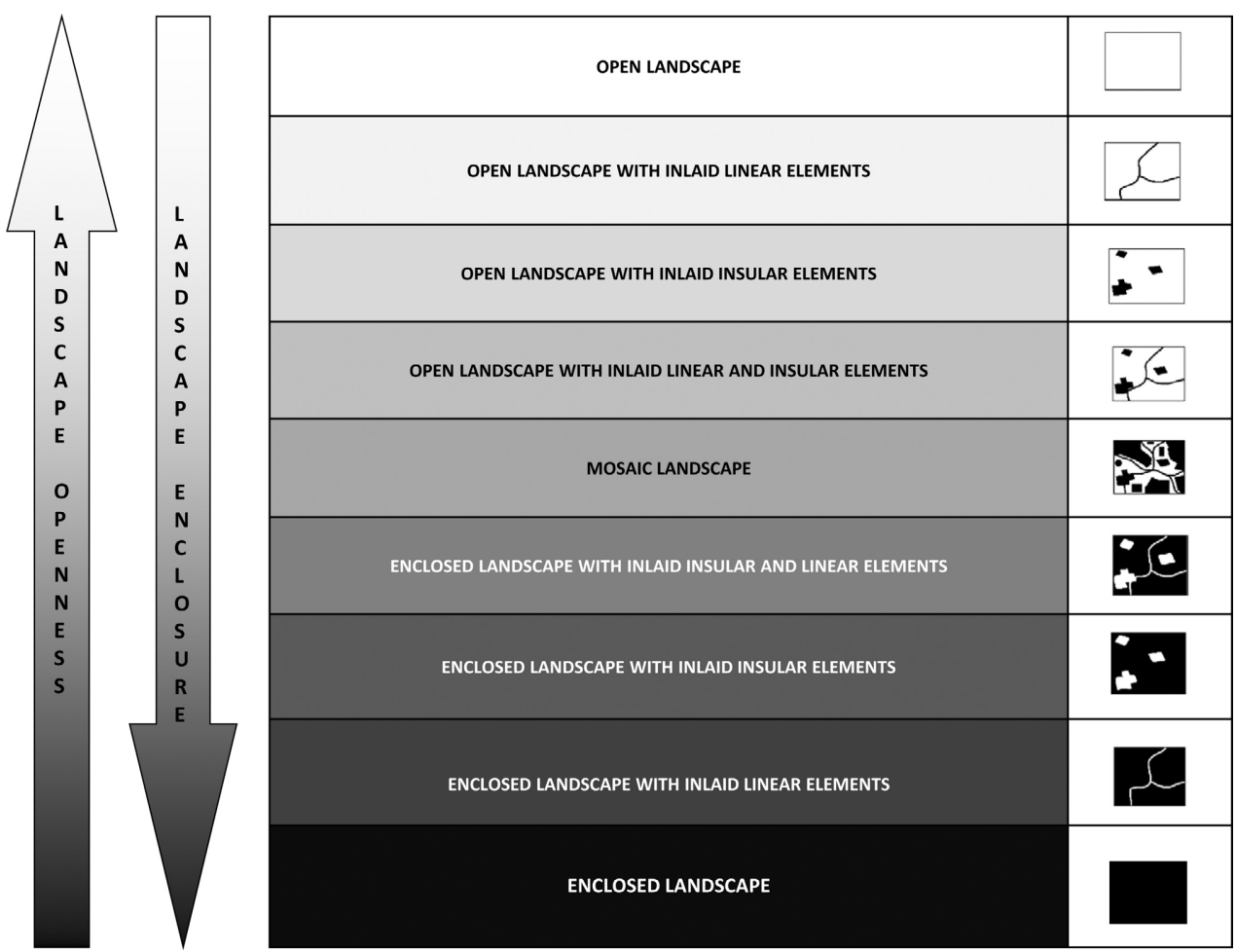

Figure 1. An ideogram showing the degree of landscape openness/enclosure in accordance with the proposed scale

visible, typically lower islands featuring different physiognomy and linear elements, e.g. a forest with a clearing and access roads;

E - enclosed with inlaid insular elements - large, physiognomically homogenous forms constitute the background, with visible, typically lower islands featuring different physiognomy, e.g. small clearings among forests, preserved patches of agricultural land among dense housing, etc.;

$\mathrm{F}$ - enclosed with inlaid linear elements large, physiognomically homogenous forms constitute the background, with visible, typically lower linear elements, e.g. river valleys in forests, roads or paths in forests or among dense housing, etc.;

G - enclosed - large, physiognomically homogenous forms with clearly 3-D characteristics, higher forms cover the horizon, e.g. forests, dense housing.
The above degrees of openness/enclosure may be combined with morphological units, which results in 36 physiognomically different potential landscape texture types (Tab. 1).

\section{Study area}

The applicability of the modified, more detailed typology of landscape texture as presented above was tested in highly anthropogenically transformed areas: Upper Silesia and the Dabrowa Coal Basin. 12 neighbouring municipalities were selected: Gorzyce, Wodzisław Śląki, Marklowice, Świerklany, Rybnik, Czerwionka-Leszczyny, Orzesze, Mikołów, Katowice, Sosnowiec and Dabrowa Górnicza. The study area covers $1021 \mathrm{~km}^{2}$. The research was conducted in the year 2015. In accordance with the physico-geographical delineation proposed by J. Kondracki (2011), the study area is located within three provinc- 
Table 1. Landscape texture types (according to the degree of openness/enclosure)

\begin{tabular}{|c|c|c|c|c|}
\hline \multirow{2}{*}{ Types of landscape texture units } & \multicolumn{4}{|c|}{ Types of land relief } \\
\hline & 1. valleys & 2. gentle slopes & 3. steep slopes & 4. plateous \\
\hline A. Open landscape & $1 \mathrm{~A}$ & $2 \mathrm{~A}$ & $3 \mathrm{~A}$ & $4 \mathrm{~A}$ \\
\hline $\begin{array}{l}\text { B. Open landscape with inlaid linear } \\
\text { elements }\end{array}$ & $1 \mathrm{~B}$ & $2 B$ & $3 B$ & $4 \mathrm{~B}$ \\
\hline $\begin{array}{l}\text { C. Open landscape with inlaid insular } \\
\text { elements }\end{array}$ & $1 \mathrm{C}$ & $2 \mathrm{C}$ & $3 \mathrm{C}$ & $4 \mathrm{C}$ \\
\hline $\begin{array}{l}\text { BC. Open landscape with inlaid linear and } \\
\text { insular elements }\end{array}$ & $1 \mathrm{BC}$ & $2 B C$ & $3 B C$ & $4 B C$ \\
\hline D. Mosaic landscape & $1 \mathrm{D}$ & $2 \mathrm{D}$ & $3 \mathrm{D}$ & $4 \mathrm{D}$ \\
\hline $\begin{array}{l}\text { EF. Enclosed landscape with inlaid insular } \\
\text { and linear elements }\end{array}$ & $1 \mathrm{EF}$ & $2 \mathrm{EF}$ & $3 \mathrm{EF}$ & $4 \mathrm{EF}$ \\
\hline $\begin{array}{l}\text { E. Enclosed landscape with inlaid insular } \\
\text { elements }\end{array}$ & $1 \mathrm{E}$ & $2 \mathrm{E}$ & $3 \mathrm{E}$ & $4 \mathrm{E}$ \\
\hline $\begin{array}{l}\text { F. Enclosed landscape with inlaid linear } \\
\text { elements }\end{array}$ & $1 \mathrm{~F}$ & $2 \mathrm{~F}$ & $3 \mathrm{~F}$ & $4 \mathrm{~F}$ \\
\hline G. Enclosed landscape & $1 \mathrm{G}$ & $2 \mathrm{G}$ & $3 \mathrm{G}$ & $4 \mathrm{G}$ \\
\hline
\end{tabular}

es and subprovinces: the Central Poland Lowland (31) (subprovince Central Poland Plains), the Western Carpathians and Subcarpathia (51) (subprovince Northern Subcarpathia), and, primarily, the Polish Uplands (34) (subprovince Silesia-Cracow Upland). This reflects high morphological diversity of the study area. Lower-order physico-geographical units, i.e. macroregions and mesoregions, are shown on the map (Fig. 2).

\section{Results}

\section{Identification of morphological units}

Within the study area, 68 morphological units were delineated (Fig. 3). The top parts of hills account for 24 plateau units, which cover $12.3 \%$ of the total study area $\left(125.6 \mathrm{~km}^{2}\right)$ (Table 2). They dominate primarily in the south, within the hills of the Rybnik Plateau (Pszów Hills), but some are also located in the central part (Mikołów Hills) and in the north (Gołonóg Hills, Zagórze). 22 steep slope units were delineated, which cover 264.67 $\mathrm{km}^{2}$ and account for $25.9 \%$ of the study area. They surround plateau areas, constituting an intermediate zone between plateaus and gentle slopes. However, there is an exception in the south, where the edge of the Rybnik Plateau (the Silesian Upland) steeply descends towards the Oder Valley (the Racibórz Basin). 13 gentle slope units cover $277.48 \mathrm{~km}^{2}$, accounting for $27.18 \%$ of the study area. They constitute a morphological intermediate zone between steep slopes and valleys, and they dominate mainly in the lower parts of the Rybnik Plateau, the Katowice Upland and the Tarnowskie Góry Hummock. Finally, 9 valley units were delineated, covering $353.53 \mathrm{~km}^{2}$ (34.62\% of the study area). These are the valleys of the following rivers (starting from the south): the Oder, the Ruda and the Nacyna, the Bierawka, the Mleczna, the Kłodnica, the Rawa, the Brynica, the Black Przemsza and the White Przemsza.

\section{Identification of landscape texture units}

Considering the 4 categories of morphological units and the 9 degrees of openness, 828 landscape texture units were delineated in the study area. Valleys were divided into 218 units, gentle slopes - into 235 units, 


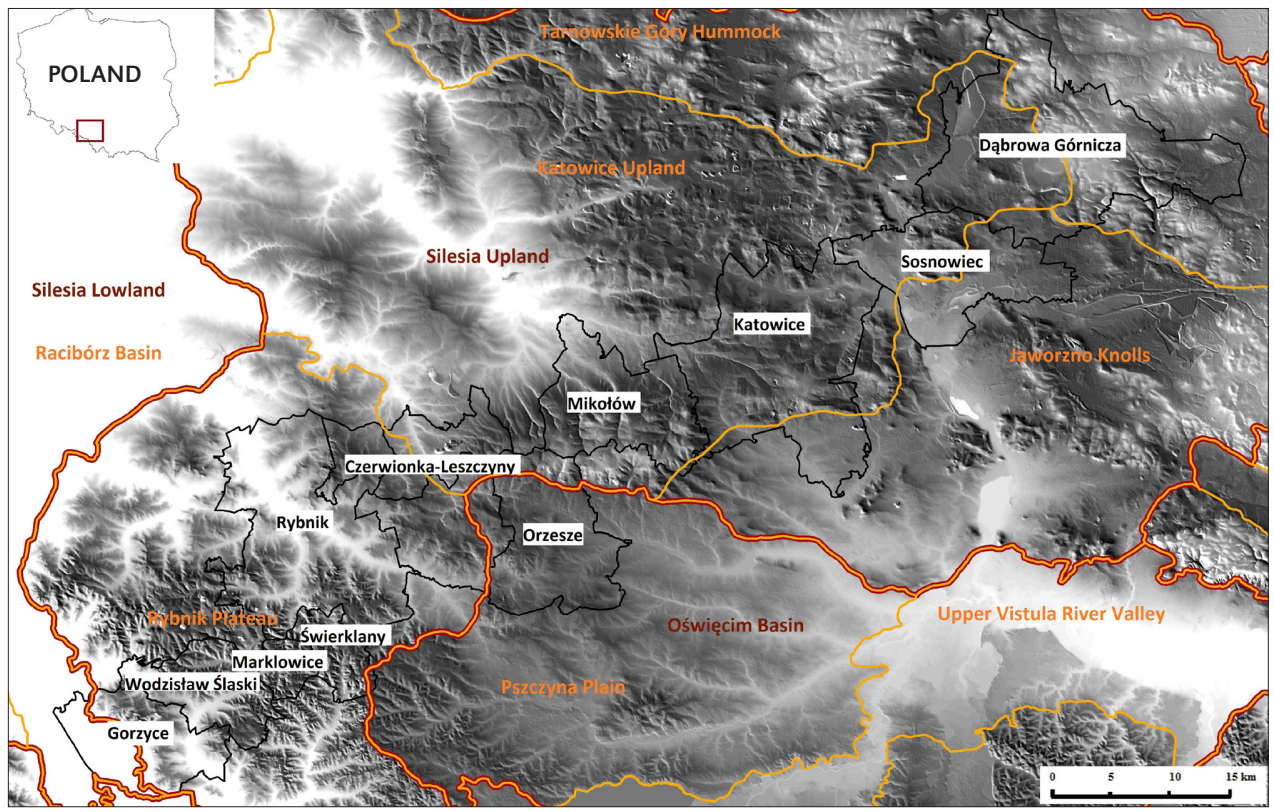

Figure 2. The study area (selected municipalities) and the physico-geographical division by Kondracki (macro- and mesoregions) against the Digital Terrain Model

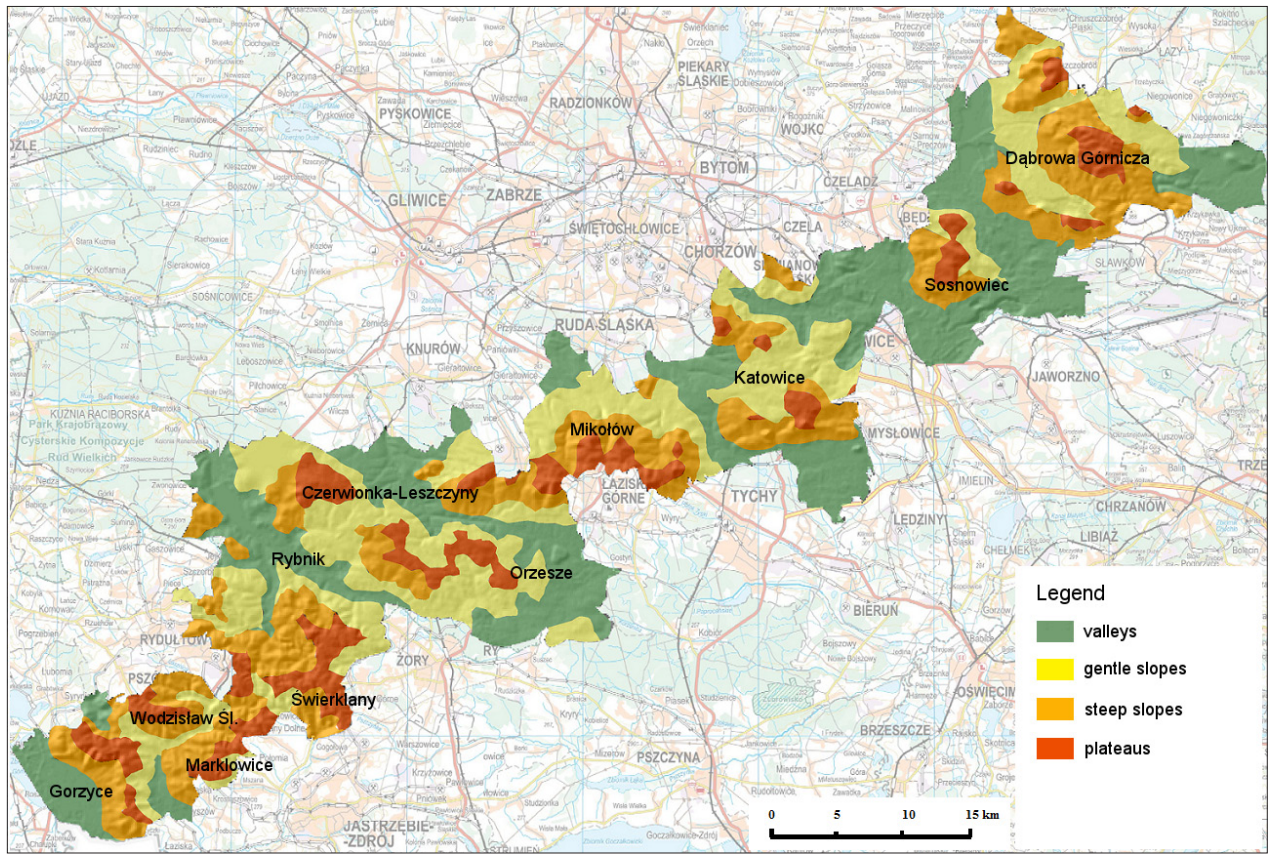

Figure 3. Morphological units in the study area against the background of the Digital Terrain Model and the topographic map 
steep slopes - into 221 units, and plateaus - into 154 units. Overall, the landscapes were divided according to their openness/ enclosure into three groups: open landscape (with 4 possible types), mosaic landscape and enclosed landscape (with 4 possible types).

\section{Open landscape units}

The open landscapes were analyzed as a total of A type open, B type open inlaid with linear elements, $C$ type open inlaid with insular elements, and BC type open inlaid with

Table 2. Number (N), area (A) and\% share (Per) of landscape texture units

\begin{tabular}{|c|c|c|c|c|c|c|}
\hline \multirow{2}{*}{$\begin{array}{l}\text { Type of landscape } \\
\text { texture units }\end{array}$} & \multicolumn{6}{|c|}{ Type of morphological units } \\
\hline & indicator & valleys & gentle slopes & steep slopes & plateaus & Total \\
\hline \multirow{3}{*}{ open landscape } & N & 10.00 & 3.00 & 4.00 & 2.00 & 19.00 \\
\hline & $\mathrm{A}\left(\mathrm{km}^{2}\right)$ & 14.25 & 1.17 & 2.46 & 1.88 & 19.76 \\
\hline & Per\% & 4.03 & 0.42 & 0.93 & 1.50 & 1.94 \\
\hline \multirow{3}{*}{$\begin{array}{l}\text { B. open landscape with } \\
\text { inlaid linear elements }\end{array}$} & $\mathrm{N}$ & 10.00 & 10.00 & 10.00 & 7.00 & 37.00 \\
\hline & $\mathrm{A}\left(\mathrm{km}^{2}\right)$ & 16.86 & 11.96 & 7.39 & 1.39 & 37.60 \\
\hline & Per\% & 4.77 & 4.31 & 2.79 & 1.11 & 3.68 \\
\hline \multirow{3}{*}{$\begin{array}{l}\text { C. open landscape with } \\
\text { inlaid insular elements }\end{array}$} & $\mathrm{N}$ & 1.00 & 2.00 & 0.00 & 0.00 & 3.00 \\
\hline & $\mathrm{A}\left(\mathrm{km}^{2}\right)$ & 0.89 & 3.46 & 0.00 & 0.00 & 4.35 \\
\hline & Per\% & 0.25 & 1.25 & 0.00 & 0.00 & 0.43 \\
\hline \multirow{3}{*}{$\begin{array}{l}\text { BC. open landscape } \\
\text { with inlaid linear and } \\
\text { insular elements }\end{array}$} & N & 70.00 & 70.00 & 71.00 & 48.00 & 259.00 \\
\hline & $\mathrm{A}\left(\mathrm{km}^{2}\right)$ & 97.65 & 63.77 & 83.15 & 44.20 & 288.77 \\
\hline & Per\% & 27.62 & 22.98 & 31.44 & 35.19 & 28.28 \\
\hline \multirow{3}{*}{ D. mosaic landscape } & N & 49.00 & 67.00 & 52.00 & 33.00 & 201.00 \\
\hline & $\mathrm{A}\left(\mathrm{km}^{2}\right)$ & 84.27 & 69.03 & 78.30 & 24.93 & 256.53 \\
\hline & Per\% & 23.84 & 24.88 & 29.61 & 19.85 & 25.12 \\
\hline \multirow{3}{*}{$\begin{array}{l}\text { EF. enclosed landscape } \\
\text { with inlaid linear and } \\
\text { insular elements }\end{array}$} & $\mathrm{N}$ & 42.00 & 46.00 & 47.00 & 36.00 & 171.00 \\
\hline & $\mathrm{A}\left(\mathrm{km}^{2}\right)$ & 110.67 & 103.88 & 64.56 & 30.40 & 309.51 \\
\hline & Per\% & 31.31 & 37.44 & 24.41 & 24.20 & 30.31 \\
\hline \multirow{3}{*}{$\begin{array}{l}\text { E. enclosed landscape } \\
\text { with inlaid insular ele- } \\
\text { ments }\end{array}$} & $\mathrm{N}$ & 6.00 & 24.00 & 24.00 & 6.00 & 60.00 \\
\hline & $\mathrm{A}\left(\mathrm{km}^{2}\right)$ & 1.12 & 16.86 & 15.85 & 2.60 & 36.43 \\
\hline & Per\% & 0.32 & 6.08 & 5.99 & 2.07 & 3.57 \\
\hline \multirow{3}{*}{$\begin{array}{l}\text { F. enclosed landscape } \\
\text { with inlaid linear ele- } \\
\text { ments }\end{array}$} & N & 23.00 & 2.00 & 2.00 & 15.00 & 42.00 \\
\hline & $\mathrm{A}\left(\mathrm{km}^{2}\right)$ & 24.75 & 2.68 & 2.87 & 11.85 & 42.15 \\
\hline & Per\% & 7.00 & 0.97 & 1.09 & 9.43 & 4.13 \\
\hline \multirow{3}{*}{ G. enclosed landscape } & $\mathrm{N}$ & 7.00 & 11.00 & 11.00 & 7.00 & 36.00 \\
\hline & $\mathrm{A}\left(\mathrm{km}^{2}\right)$ & 3.06 & 4.67 & 9.89 & 8.35 & 25.97 \\
\hline & Per\% & 0.87 & 1.68 & 3.74 & 6.65 & 2.54 \\
\hline \multirow{3}{*}{ Total } & N & 218.00 & 235.00 & 221.00 & 154.00 & 828.00 \\
\hline & $\mathrm{A}\left(\mathrm{km}^{2}\right)$ & 353.52 & 277.48 & 264.47 & 125.60 & 1021.07 \\
\hline & Per\% & 34.62 & 27.18 & 25.90 & 12.30 & 100.00 \\
\hline
\end{tabular}


insular and linear elements). Such landscapes cover $34.33 \%$ of the study area $\left(350.48 \mathrm{~km}^{2}\right)$ (Table 2), however, most of them possess open backgrounds, but inlaid with numerous linear and insular elements (BC type). Analyzing the distribution of open landscapes (with a high degree of openness), we see that most of them are located in river valleys (the Odra Valley in the municipality of Gorzyce, the Leśnica Valley in Wodzisław Ślaski, the Ruda and the Nacyna Valley in Rybnik, the Brynica Valley in Katowice, the Black Przemsza Valley including the water bodies Pogoria I, II, III and IV) and in agricultural areas (CzerwionkaLeszczyny, Mikołów, southern and eastern parts of Dąbrowa Górnicza) (Fig. 4A).

\section{Mosaic landscape units}

Mosaic landscapes (D type) are characterized by ecological diversity of the landscape and reflect physiognomic heterogeneity of the landscape. They cover $25.12 \%$ of the study area $\left(256,53 \mathrm{~km}^{2}\right)$. The largest patches of mosaic landscape are observable in the northern part of the study area, particularly in the city centres of Sosnowiec and Daprowa Górnicza, where housing dominates, however, it is mixed with services and industrial facilities, home gardens and wastes. Considering the central part of the study area, mosaic landscapes are observable in Katowice in the Brynica Valley and in the central districts along the main southern route (Piotrowice, Ligota, Brynów). In the southern part, mosaic landscapes are scattered and have the form of small patches. They mostly result from the on-going suburbanization process (new housing consisting of detached single-family houses covering what used to be agricultural land, accompanied by the establishment of shops, services, sports and cultural facilities) (Fig. 4B).

\section{Enclosed landscape units}

Enclosed landscapes may take the form of forests or areas covered by dense housing. They are considered as a total of all enclosed landscape types, i.e. enclosed, enclosed inlaid with linear elements, enclosed inlaid with insular elements and enclosed inlaid with insular and linear elements (EF, E, F and G). They cover $40.55 \%\left(414.06 \mathrm{~km}^{2}\right)$ of the study area. They are located in densely inhabited city centres of the Katowice Conurbation: Katowice (northern part), Sosnowiec (western part), Dabrowa Górnicza (south-western districts), Mikołów (southern part) and in the cities of the Rybnik Conurbation (the centres of Rybnik and Wodzisław Ślaski). Moreover, such landscape units were delineated in forest areas: the Rybnik Forests (including the Natural Scenic Area of Cistercian Landscape Compositions in Rudy Wielkie), the Pszczyna Forests (the Murcki Forest and the Panewniki Forest in the southern part of Katowice) and the forests within the Tarnowskie Góry Hummock (Fig. 4C).

\section{Discussion}

Open landscapes are usually large areas with natural land cover (vegetation, water). This does not apply to relatively rare large areas with anthropogenic land cover (e.g. concrete airstrips). The main function of open landscapes consists in improving the ecological structure of the landscape. Usually, as the anthropopressure in open landscapes is smaller than in enclosed landscapes, they are used as recreational areas, agricultural land and nature conservation areas. Therefore, open landscapes usually should be treated as buffer zones around dense urban housing, with the aim of lowering the high pressure on the environment and the landscape (DabrowskaMilewska 2010). The occurrence of open landscapes is associated with the forms of landform and landscape function. They dominate in river valleys, performing agricultural functions, which is associated with good soil and climate conditions, eg. the Odra valley in the Racibórz Basin. To a lesser extent, they are located in the areas of upland and slopes, performing agricultural functions, eg. the Rybnik Plateau. In addition, they occur in river valleys performing recreational func- 


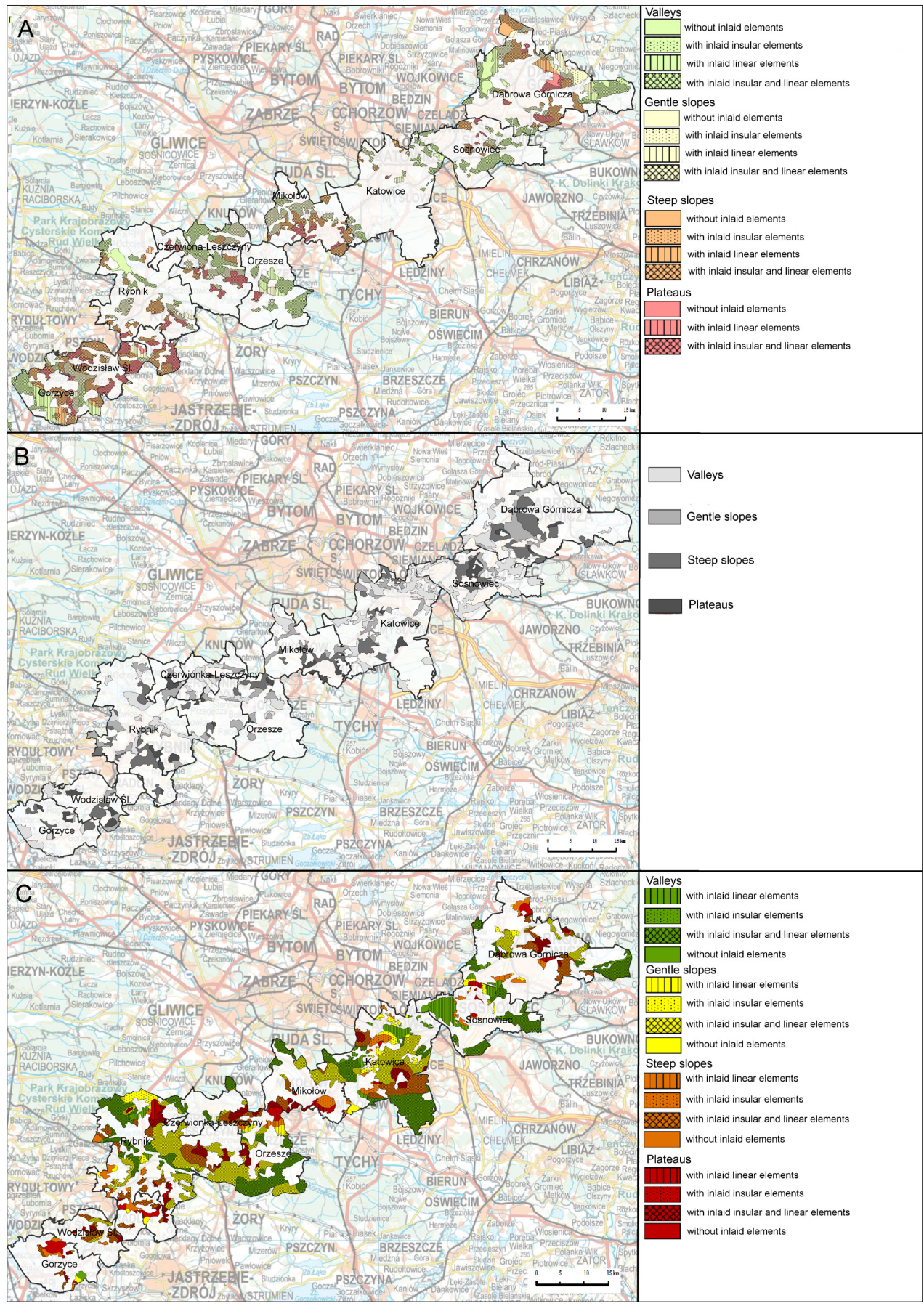

Figure 4. Landscape texture types: A - open landscape, B - mosaic landscape, C - enclosed landscape against the background of the topographic map 
tions, eg. Pogoria reservoirs on the Czarna Przemsza River (Katowice Upland) or Rybnik Reservoir on Ruda (Rybnik Plateau). Moreover according to D. Wascher (2005), planners see the degree of landscape openness as a feature of traditional landscapes that should be conserved. In accordance with planning guidelines, they should be protected against development. G. Weitkamp (2010) also refers to this view, expressing the belief that open landscapes can be culturally important, as they are usually unique and historically important.

A landscape remains open if the if the accumulation of inlaid elements (diversifying/ disturbing elements) still allows us to identify a homogeneous background. When the density of inlaid elements is so high that a homogeneous background is not perceivable, we deal with a mosaic landscape. A typical example of the process of open landscapes turning into mosaic landscapes is spreading of housing and services into what used to be agricultural land. Mosaic landscapes may also result when the structure of enclosed landscapes is disturbed by new linear and insular elements, for example when housing estates are build on forest land or blocks of tenements are demolished among dense urban housing (Antrop 2004). Mosaic landscapes are characterized by great diversity of land cover, both considering the degree and the type of the cover. A homogeneous landscape background is not identifiable, there are numerous objects with diverse shapes and sizes. This makes the impression of spatial chaos, haphazardness and disharmony. Mosaic landscapes always disturb the original, unspoilt structure of open or enclosed landscapes. In spite of their diversity, mosaic landscapes in anthropogenically transformed areas are seen in a negative light as having low value, disharmonious and unwanted.

Landscape enclosure results from a landscape texture composed of high and dense elements. Enclosed landscapes are characterized by homogeneous structure and high degree of cover. From ground level, it is impossible to observe landscape elements that are far off, only the closest elements are visible, which negatively influences the visual value of the landscape, hampering long-distance observation (Marcinkowski 2016). Enclosed landscapes can in fact be assessed only if we take into account the origin of high elements that create them. In the case of naturogenic origin (eg. tree planting), it is usually a desirable feature, whereas in the case of anthropogenic origin (eg. dense, compact buildings) - an undesirable feature.

However, even the process of open landscapes turning into enclosed landscapes through natural vegetation growth is seen as a negative, unwanted development. This is pointed out by Plit and Myga-Piatek (2014), who note that during the last 70 years landscapes in Poland have been undergoing "enclosing". This is caused by the urban sprawl, i.e. high urban housing spreading to what used to be agricultural land (Hennig et al. 2015), and, on the other hand, by nature conservation measures consisting in letting the landscape regenerate on its own. In anthropogenic enclosed landscapes, the pressure on the landscape is the biggest when the landscape is completely covered with anthropogenic elements (lack of natural insular and linear elements).

As the degree of anthropogenization rises, there are more and more elements that disturb the "unspoilt" open landscape (Collinge 2009). The high share of mosaic landscapes in the study area (25.12\%) combined with the high shares of landscapes inlaid with insular and linear elements (BC type - 28.28\% and EF type - 30.31\%) reflect far-going anthropogenic transformation. Transformed landscapes are characterized by high fragmentation, and their units are usually small (Schmiedel \& Culmsee 2016). Consequently, when analyzing anthropogenically transformed landscapes, what we need is close attention to detail in order to appreciate their diversity. Only sufficiently detailed analyses guarantee precision and reliability of research. Consequently, the modified typology proposed here may be evaluated as suitable for analyses such as the one focus- 
ing on the selected municipalities of Upper Silesia and the Dabrowa Coal Basin.

\section{Conclusions}

1. The study area is characterized by diversified landscape texture, which results from both its physico-geographical location (at the boundary of three provinces) and the high degree of transformation.

2. The domination of landscape texture units with inlaid (linear and insular) elements and mosaic landscapes reflects the high degree of anthropogenic transformation. Anthropogenically transformed landscapes are characterized by a high degree of perforation for enclosed landscapes and a high degree of insularity for open landscapes.

\section{References}

Antrop M. 2004. Landscape change and the urbanization process in Europe. Landscape and Urban Planning, vol. 67, no. 1-4, pp. 9-26.

BelL S., 2004. Elements of visual design in the landscape. London: Spon Press.

BogDANOWSKI J., 1999. Metoda jednostek i wnętrz architektoniczno- krajobrazowych (JARK-WAK) w studiach i projektowaniu. Kraków: Wydawnictwo Politechniki Krakowskiej.

Brossard T., Joly D., 1996. Mapping the visual content of landscape: A regional approach by means of Corine Land Cover and digital elevation model. IALE International Conference "Landscape transformation in Europe. Practical and theoretical aspects" 12 October 1996 Warsaw.

Chmielewski T.J., Butler A., KuŁak A., 2018. Landscape's physiognomic structure: Conceptual development and practical applications. Landscape Research, vol. 43, no. 3, pp. 410-427.

Chmielewski T.J., Chmielewski Sz., 2015. Podstawowe przyrodnicze jednostki przestrzenne, a spójność i stabilność ekologiczna systemów krajobrazowych. Problemy Ekologii Krajobrazu, vol. 40, pp. 145-160.
3. Analyses of landscape texture types play a crucial role in preparation of planning documents, e.g. urban spatial management plans, as they identify areas that should be covered by open landscapes, acting as buffer zones for urbanized areas.

4. The more detailed landscape texture typology proposed here has been verified as to its suitability for analysis of anthropogenically transformed landscapes. It may be successfully employed to study landscape texture in urban areas.

Editors' note:

Unless otherwise stated, the sources of tables and figures are the authors', on the basis of their own research.

Chmielewski T.J., Sowińska-Świerkosz B., Kutak A., Chmielewski Sz., 2014. Krajobrazy Roztocza: Dziedzictwo natury i kultury. Lublin: Wydawnictwo Uniwersytetu Przyrodniczego, Agencja Wydawniczo-Reklamowa Magic.

Coeterier J.F., 1996. Dominant attributes in the perception and evaluation of the Dutch landscape. Landscape and Urban Planning, vol. 34, no. 1, pp. 27-44.

Coluinge S.K., 2009. Ecology and fragmented landscapes. Baltimore: John Hopkins University Press.

Cömertler S., 2007. Rola terenów otwartych w podnoszeniu atrakcyjności i jakości życia miejskiego. Czasopismo Techniczne, vol. 104, no. 1-A, pp. 25-34.

Dąrowska-Milewska G., 2010. Standardy urbanistyczne dla terenów mieszkaniowych wybrane zagadnienia. Architecturae et Artibus, vol. 2, no. 1, pp. 17-31.

De Veer A.A., Burrough P.A., 1978. Physiognomic landscape mapping in The Netherlands. Landscape Planning, vol. 5, no. 1, pp. 45-62.

Fischer J., Lindenmayer D.B., Montague-Drake R., 2008. The role of landscape texture in conservation biogeography: a case study on birds in south-eastern Australia. Diversity and Distributions, vol. 14, pp. 38-46. 
Hennig E.I., Schwick C., Soukup T., Orlitová E., Kienast F., Jaeger J.A.G., 2015. Multi-scale analysis of urban sprawl in Europe: Toward a European de-sprawling strategy. Land Use Policy, vol. 49, pp. 483-498.

Kaplan R., Kaplan S., Brown T., 1989. Environmental preference: A comparison of four domains of predictors. Environment and Behavior, vol. 21, no. 5, pp. 509-530.

KondRACKI J., 2011. Geografia regionalna Polski. Warszawa: Wydawnictwo Naukowe PWN.

MARCINKOWSKI R., 2016. Intensywna zabudowa a ochrona walorów krajobrazu. Czasopismo Inżynierii Ladowej, Środowiska i Architektury, vol. 33, no. 63, pp. 263-270.

Miller D.R., LaW A.N.R., 1997. The mapping of terrain visibility. The Cartographic Journal, vol. 34, no. 2, pp. 87-91.

Plit J., Myga-Piatek U., 2014. The degree of landscape openness as a manifestation of cultural metamorphose. Quaestiones Geographicae, vol. 33, no. 3, pp. 145-154.

Plit J., Mrga-Piątek U., 2016. Investigating openness of the cultural landscape - a methodological proposal. Geographia Polonica, vol. 89, no. 2, pp. 129-140.

Plotnick R.E., Gardner R. H., O’Neill R.V., 1993. Lacunarity indices as measures of landscape texture. Landscape Ecology vol. 8, no. 3, pp. 201-211.

RichuING A., 1992. Podstawy metodyczne oceny wizualnej atrakcyjności krajobrazu [in:] A. Richling (ed.), Metody oceny środowiska przyrodniczego, Gea 2, Warszawa: Wydział Geografii i Studiów Regionalnych UW, pp. 45-46.

Rogge E., Nevens F., Gulinck H., 2007. Perception of rural landscapes in Flanders: Looking beyond aesthetics. Landscape and Urban Planning, vol. 82, no. 4, pp. 159-174.

Schmiedel I., Culmsee H., 2016. The influence of landscape fragmentation, expressed by the 'Effective Mesh Size Index', on regional patterns of vascular plants species richness in Lower Saxony, Germany. Landscape and Urban Planning, vol. 153, pp. 209-220.
Solon J., Chmielewski T.J., Myga-Piątek U., KisTOWSKI M., 2015. Identyfikacja i ocena krajobrazów Polski - etapy i metody postępowania $w$ toku audytu krajobrazowego w województwach. Problemy Ekologii Krajobrazu, vol. 40, pp. 55-76.

Szulczewska B., Kaliszuk E., 2005. Koncepcja systemu przyrodniczego miasta: Geneza, ewolucja i znaczenie praktyczne. Teka Komisji Architektury, Urbanistyki i Studiów Krajobrazowych - OL PAN, vol. 1, pp. 7-24.

ŚLESZYŃSKI P., 2007. Ocena atrakcyjności wizualnej mezoregionów Polski. [in:] Z. Mikulski (ed.), Znaczenie badań krajobrazowych dla zrównoważonego rozwoju. Profesorowi Andrzejowi Richlingowi w 70. rocznice urodzin i 45-lecie pracy naukowej, Warszawa: Wydział Geografii i Studiów Regionalnych UW, pp. 697-714.

ULRICH R.S., 1979. Visual landscapes and psychological well-being. Landscape Research, vol. 4, no. 1 , pp. 17-23.

WARD THOMPSON C., 2011. Linking landscape and health. Landscape and Urban Planning, vol. 99, pp. 187-195.

WASCHER D. (ed.), 2005. European landscape character areas: Typologies, cartography and indicators for the assessment of sustainable landscapes. Wageningen: Landscape Europe, Alterra-rapport 1254.

Weitkamp G., 2010. Capturing the view. A GIS based procedure to assess perceived landscape openness. Thesis submitted in partial fulfillment of the requirements for the degree of doctor. Wageningen: Wageningen University.

Weitkamp G., Bregt A., Van Lammeren R., 2011. Measuring visible space to assess landscape openness. Landscape Research, vol. 36, no. 2, pp. 127-150. 